\title{
Debbie Travis, Reigning Queen Of Renovations: An Entrepreneurial Case Study On Finding Your Hedgehog
}

Sean Wise, Ryerson University, Canada

Madelon Crothers, Ryerson University, Canada

\begin{abstract}
Debbie Travis, awarded the titled "Reigning Queen of Renovations" by TV host Regis Philbin, is an international television personality, best-selling author, interior designer, syndicated newspaper columnist and, most importantly, a beloved entrepreneurial icon in the home decorating industry around the world (The Naked Entrepreneur, 2013). Travis had a fast ride to the top decorating and design world, making the most of her opportunities as she went. With no formal decorating or design experience or training, Debbie was able to find her personal hedgehog. She went on to become an award-winning author, with all eight books becoming best sellers. Some of her notable titles include: The Painted House, Decorating Solutions, Weekend Projects, Living and Dining Rooms, Kids' Rooms, Bedrooms, Kitchens and Baths, and Facelift (Debbie Travis, 2013). She started her own productive painting and design business, which set her off to be a leader in the paint and faux finishing design trend that was hitting North America (The Naked Entrepreneur, 2013).

Following a very successful launch of her product line at Canadian Tire, Travis starred in her own television show, From the Ground Up with Debbie Travis. Double dipping in the house and home industry allowed Debbie to follow her two passions of television and home decorating while being very successful at both (Debbie Travis, 2013). When Travis was becoming a known personality in the decorating lifestyle industry, many people asked her, "How did you manage to get on Oprah?" Debbie's answer was pretty simple, "I asked." Travis was not afraid of the producers or talk show hosts saying, "No." She figured there was no harm in asking. Her theory only proved to be successful as she was on all four shows with great success and response from the experience. With Travis' unique background, Debbie is a sought after inspirational speaker for various women's conventions, business organizations, and design and decorating shows around the globe. She is constantly looking for the next opportunity to add to her Debbie Travis ever-building empire.
\end{abstract}

Keywords: Double Dipping; Hedgehog; Opportunity Spotting; Adversity Quotient; Talent Triangle: Domain Knowledge, Operational Experience; Business Acumen

\section{INTRODUCTION}

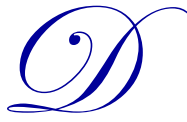

ebbie Travis did not know what she wanted to do when she finished university, but she knew she wanted to love her job. She loved helping her friends with home design and décor and she loved completing household projects by herself, rather than hiring someone to do it. Debbie often found herself trying to figure out how she could make a career out of something she enjoyed doing in her spare time.

An entrepreneur's hedgehog (an understanding of what the entrepreneur can be the-best-in-the-world at, what their passion is, and the economic engine associated with (Collins, 2001) is often the driving force behind their business model. Entrepreneurs often have to take a step back and evaluate what forms their own hedgehog, asking 
themselves such questions as "What do they like? What do they have experience in? How can they contribute to the idea? How will the idea make money?" Debbie did not find her hedgehog overnight. She spent a lot of time thinking and evaluating the different options, all while attempting to maximize her opportunities. Once she determined what her personal hedgehog was, she spent many years building what is now her own empire.

\section{BACKGROUND}

Debbie Travis, awarded the titled "Reigning Queen of Renovations" by TV host Regis Philbin, is an international television personality, best-selling author, interior designer, syndicated newspaper columnist and, most importantly, a beloved entrepreneurial icon in the home decorating industry around the world (The Naked Entrepreneur, 2013). Her long list of awards includes: 4 Gemini's and 21 nominations for television production and hosting, The Libris Award for Book of the Year, The Crystal Award for Women of Excellence, as well as The McGill Award for Person of the Year (Debbie Travis, 2013). She had a fast ride to the top decorating and design world, making the most of her opportunities as she went. With no formal decorating or design experience or training, Debbie was able to find her hedgehog - the answer entrepreneurs get when they ask themselves three questions: 1) What am I deeply passionate about?, 2) What drives my economic engine?, and 3) What can I be the best-in-the-world at? (Jim Collins, 2001) - by combining her passion of women, interest in home transformation and design, knowledge in DIY (do-it-yourself) and her experience in television and production.

Debbie spent her adolescent years growing up in Rochdale, Lancashire (Debbie Travis, 2013) and six years of her early adulthood as a model. After completing a degree at Art College, she transformed her combined experience and took the opportunity to become a producer for several British television networks (The Naked Entrepreneur, 2013). When Travis was becoming comfortable in the producer role, Debbie decided it was time for her next challenge.

There was not a particular position or career label that Travis was after, but she knew that she wanted to love her job. Debbie had always been interested in decorating and design. She thought to herself, was there a way that she could combine her experience as a producer with what she liked to do in her spare time? Travis began writing manuscripts for a series of how-to design and decor books in hopes there was a chance they would be picked up by a North American publishing company (The Naked Entrepreneur, 2013).

Martha Stewart had become popular in the United States at the same time Travis was writing manuscripts for her decorative how-to books. Debbie had sent her drafts to various publishing companies in the United States and had conference calls about potential opportunities, but no big name publishing companies had immediately presented a book deal (The Naked Entrepreneur, 2013). Debbie had received more than one response indicating that they were "not interested at this time."

\section{GETTING STARTED}

Travis flew to New York City for a meeting with a smaller publishing company that had expressed interest in her books. She knew that she had to make the most of the three days she was going to be in the city. The large publishing companies had told her they were not available for meetings and to touch base next time she would be in America. Debbie was not fearful of their 'no' response and decided she would not waste the opportunity of being in New York. After her meeting with the smaller publisher, Debbie walked to the front door of Random House Publishing and called up to one of the editors she had spoken to previously on the phone. When Debbie asked the editor on the phone if she had time to see her, the woman responded, "Perhaps, when are you thinking of coming?" (The Naked Entrepreneur, 2013).

Debbie responded quickly, "Well how about now? I am downstairs in the lobby."

Startled, the editor responded, "Okay, I will be down in the lobby shortly."

A little taken back by Debbie's confidence to show up on the spot, she took Debbie into a room filled with stacks and stacks of manuscripts. She turned to Travis and said, "Tell me why yours is 10 times better. What can you do that Martha Stewart or any of these manuscripts can't?" (The Naked Entrepreneur, 2013). 
This was not the first time that Travis had been told she was one of many women trying to make it in the home decor industry, but she did not let that discourage her one bit. Her high adversity quotient and true belief that she was the best allowed her to continue her quest to become the queen of home renovation. The Random House editor told her that she would get a response at the end of the following week. Debbie left the large Manhattan office lobby feeling good about her decision. Travis was hopeful when she answered the phone call later in the week and became even more excited when they offered her not only a deal for one book, but for eight. She went on to become an award-winning author, with all eight books becoming best sellers. Some of her notable titles include: The Painted House, Decorating Solutions, Weekend Projects, Living and Dining Rooms, Kids' Rooms, Bedrooms, Kitchens and Baths, and Facelift (Debbie Travis, 2013).

After meeting Hans Rosenstein at the 1985 Cannes Film Festival, she fell instantly in love and the couple married only two weeks later after they made the decision to move to Montreal, Quebec - Rosentein's home city. Although Debbie did not recognize it at the time, this pivotal moment would change her life.

Once landed in Montreal, Debbie did not waste any time getting down to business. She redecorated their old Victorian style house using paint effects (a new concept at the time). Debbie's internal locus of control told her that she, herself, was responsible for making the most of her design aesthetic, experience, and ideas. After Travis completed the redecorating of her family home, she formed a small decorating business in Montreal, which quickly grew to become much larger in a short amount of time. She then started her own productive painting and design business which set her off to be a leader in the paint and faux finishing design trend that was hitting North America (The Naked Entrepreneur, 2013). Her company was commissioned to design and decorate large department stores in Montreal and Toronto, auditoriums, theatres, as well as grand reception halls (Debbie Travis, 2013). After a handful of large decorating projects that she and her small team completed, Debbie knew she had something at her fingertips, but it was up to her to make it happen.

\section{THE VALUE OF SOCIAL CAPITAL}

Social capital (an economic phrase that refers to the connections between individuals that can be of high value to one another; networks that include people who trust each other and are leaders within the industry can be a powerful asset (Wise, 2012) is a concept that Debbie continuously discusses in interviews and articles around the world. Very early on in London, England, her friend Richard Branson said to her, "You have to be great." (The Naked Entrepreneur, 2013) She took his advice very seriously and made the most of any opportunities to meet with industry leaders or people that could help her achieve her goals of getting her book(s) published and becoming a known name within the industry.

Travis knew that she had found her hedgehog (an entrepreneur's understanding of what he or she can be best at) when she combined her two passions of design and television production through the creation of North America's first decorating shows - Debbie Travis' The Painted House. Within a short time of it airing on televisions across Canada, The Painted house was a necessary must-see for devoted viewers in over 80 countries worldwide (The Naked Entrepreneur, 2013).

The Painted House had 13 very successful seasons on the air before her next venture - Debbie Travis' Facelift - was launched (Debbie Travis, 2013). She saw an unmet need in the television industry for a design reality show, so she knew she had to make the most of the opportunity that was in front of her. Almost immediately it was a worldwide hit. Debbie and her team's hard work paid off to create a television show developed - by women and for women - that was a combined mix of reality TV, top-level design, with a hint of soap opera drama (Debbie Travis, 2013).

In 2005, Debbie spotted the opportunity to launch her own line of paint and home products (Debbie Travis, 2013). She had the domain knowledge and business acumen to successfully add this new venture to her home decorating empire and knew she had to find someone with the operational knowledge to bring it to market. The addition to her portfolio created a new brand of Debbie under the name of Debbie Travis Branding Inc., which is headquartered in Toronto, Ontario (Debbie Travis, 2013). She partnered with Canadian retailer Canadian Tire and has continued to expand her line of home furnishings and plethora of paint and painting materials. Next up: Television. 


\section{LEVERAGING A PERSONAL BRAND}

Following a very successful launch of her product line at Canadian Tire, Debbie starred in her own television show - From the Ground Up with Debbie Travis. Double-dipping in the house and home industry allowed Debbie to follow her two passions of television and home decorating while being very successful at both (Debbie Travis, 2013). On the prime time television show, Debbie searched for a chief designer for her newest venture at the time - Debbie Travis Designed Condominiums (DTDC). DTDC was a real estate company that she collaborated with Tribute Communities (Debbie Travis, 2013). She knew how important the talent triangle was when taking on a new venture, so she took careful consideration when choosing whom to collaborate with for this project.

\section{CONCLUSION}

Debbie's latest venture is a hotel retreat for women in Tuscany (Debbie Travis, 2013). Travis was able to combine a new-found passion for olive oil with her continuous passion for women and her love of the Italian countryside all in one. Knowing her audience was key for Debbie when she started developing the hotel and property in Tuscany and she knew what she needed for the perfect combination of food, hospitality, adventure, and atmosphere for her majority women audience. The hotel retreat provides an experience like no other for women from around the globe, it is a week filled with wine, laughter, delicious food and tours of the immediate area. Debbie plans on letting men join in on the adventure in Tuscany in the future, but for now, it is women only.

With her unique background, Debbie is a sought-after inspirational speaker for various women's conventions, business organizations and design and decorating shows around the globe. She is constantly looking for the next opportunity to add to her Debbie Travis ever building empire.

\section{DISCUSSION QUESTIONS}

1. What experiences or situations do you think helped in Debbie's quest to find her personal hedgehog?

2. What do you think was the driving force behind Debbie's aggressive approach with the publishing editors?

3. How was Debbie able to double dipping?

4. What made Debbie different from other female decorators and designers who were active within the market (e.g., Martha Stewart)?

\section{AUTHOR INFORMATION}

Dr. Sean Wise is a professor of entrepreneurship at the Ted Rogers School of Management at Ryerson University in Toronto. He has over 15 years of seed funding experience and has helped found five business ventures of his own. Sean majored in engineering and economics at Carleton University, earning a law degree and MBA from the University of Ottawa, and has recently completed his PhD in Business from the Adam Smith Business School at the University of Glasgow. E-mail: sean.wise@ ryerson.ca (Corresponding author)

Madelon Crothers is a graduate student in Digital Media at Ryerson University in Toronto, Ontario. She is a graduate of St. Lawrence College in Kingston, Ontario, and completed her Bachelor of Commerce at Ryerson University in 2011. E-mail: madelon.crothers@ ryerson.ca

\section{REFERENCES}

1. Collins, Jim (2001). Good to Great: Why some companies make the leap...and others don't. Retrieved 2013 29-November from Jim Collins. New York: HarperCollins.

2. Debbie Travis. (2013). About Debbie Travis. Retrieved 2013 10-November from Debbie Travis: http://www.debbietravis.com/debbie/biography

3. The Naked Entrepreneur. (2013, March 31). Debbie Travis. Retrieved 2013 10-November from The Naked Entrepreneur: http://www.youtube.com/watch?v=9Pi_LCEjH7s

4. The Painted House Productions. (2013). The Painted House. Retrieved 2013 11-November from Debbie's Bio: http://www.painted-house.com/corner/debbies_bio.php 
5. Wise, S. (2010, April 6). The Talent Triangle. The Globe and Mail from

http://www.theglobeandmail.com/report-on-business/the-talent-triangle/article1099632/?page=all

6. Wise, S. (2012). Hot or Not: How to know if your business idea will fly or fail? Toronto, Ontario, Canada: Ryerson Entrepreneurship Institute. 


\section{TEACHING NOTES/KEY CONCEPTS}

\section{X Rule}

Definition: In order to displace incumbents, a new solution must be exponentially better, faster, cheaper, stronger, etc.; being a little better is not enough (Wise, 2012).

Debbie believed that her way of DIY (do-it-yourself) was 10X better then Martha Stewart and the other female decorators and designers on the market because of her design esthetic, methods, and trademarked painted finish style of wall décor.

\section{Adversity Quotient}

Definition: the capacity of the person to deal with challenges and adversities in their life; the science of human resilience.

Debbie's climb to the top was not an easy one. More than once, she was told by industry leaders, editors, producers and other designers that she was not the only one trying to be the leader in the design and décor industry. She had to continuously prove to herself and others that she was the one to have her books published or to be the one to have a television show. Debbie has a high adversity quotient because she was able to push past her critics and successfully move forward.

Specific examples of Debbie's adversities:

1. The Random House editor did not want to meet with her; Debbie had to arrive in the lobby of their offices and insist on having a meeting.

2. Her father was not as certain as Debbie was of her success.

3. She had no formal training in décor or design when she first started writing manuscripts, resulting in her having to prove her concept to editors, television producers, etc., even more than someone with formal, well-known training or an education background.

\section{Double Dipping}

Definition: an entrepreneurial axiom referring to an activity that generates multiple benefits and revenue streams (Wise, 2012)

Debbie double-dipped when she started to expand her business further than the television shows. She authored eight best-selling books, including The Painted House, Decorating Solutions, Weekend Projects, Living and Dining Rooms, Kids' Rooms, Bedrooms, Kitchens and Baths, and Facelift. She then went on to produce and host a reality show to search for a Chief of Design. When it came time to join forces with Canadian Tire to launch her home furnishings, Debbie once again double dipped her network expertise to make the most of her skills.

\section{Hedgehog}

Definition: It is not a goal to be the best, a strategy to be the best, an intention to be the best, or a plan to be the best; it is an understanding of what the entrepreneur can be the best at (Wise, 2013).

Debbie's hedgehog is composed of her three passions:

1. Women

2. Décor and design

3. Television and producing 


\section{Opportunity Spotting}

Definition: Opportunities can come from many different sources, but is often driven by an unmet need in the marketplace; the larger the need (either by intensity or population), the quicker the adoption (Wise, 2012).

Based on her experience in renovating their Victorian home in Montreal, Debbie recognized an opportunity to provide other women with resources to learn similar skills and enable them to redesign and decorate their own homes. She knew women wanted to do it themselves, but they needed the instruction.

\section{Talent Triangle (Domain Knowledge, Operational Experience, and Business Acumen)}

Definition: Attributes of successful management teams include three elements - business acumen, operational experience, and domain knowledge. All elements form the three corners of the talent triangle (Wise, 2010).

1. Business Acumen: Skills and experience in the development of strategy and the execution of business planning; example, the new CEO had run similar sized companies before; he had a lot of business acumen to share (Wise, 2012).

2. Domain knowledge: Understanding the customers and the industry in your business domain (Wise, 2012)

3. Operational Experience refers to the founders' prior know-how with regard to the building and delivery of the solution; example, as the startup was producing apps for the iPhone, some additional operational experience in mobile software was recruited (Wise, 2012).

From the beginning when she developed her business in Montreal all the way to looking for a company or brand to join forces with to launch her brand at Canadian Tire, Debbie brought the domain knowledge of home decorating and designing. She had to be sure she found partners and people who had operational experience and strong business acumen to complete her talent triangle. 


\section{NOTES}

